\title{
СУБ'ЄКТИ ФОРМУВАННЯ, РЕАЛІЗАЦІЇ ТА ЗАБЕЗПЕЧЕННЯ АНТИКОРУПЦІЙНОї ПРАВОВОЇ ПОЛІТИКИ В УКРАЇНІ
}

Калугіна І. 0.

Стаття присвячена дослідженню повноважень і діяльності суб'єктів формування, реалізації та забезпечення антикорупційної правової політики в Україні. Обгрунтовано, що впродовж останніх десятиліть корупція залишається однією з найнебезпечніших проблем, яка загрожує нормальному економічному та політичному розвитку держави. Поширення корупції у світі прискорюється в умовах глобалізації, оскільки економічні кризові явища виходять далеко за межі національних держав та набувають міжнародного значення. Для України зазначена проблема відзначається особливою гостротою: корупційні прояви в державі охопили практично всі сфери суспільного життя, набули ознак системності і перетворились на загрозу національній безпеці, що зумовлює особливу важливість реалізації заходів протидії та боротьби з нею. 3 цією метою в Україні в період з 2014 по 2020 рр. було прийнято низку законодавчих актів, якими був окреслений вектор розвитку антикорупційноі реформи та закладено основу для створення спеціалізованих антикорупційних органів.

Доведено, що ключову роль у формуванні та реалізації антикорупційної політики в державі відіграє Національне агентство з питань запобігання корупції, яке слід вважати органом регуляції та загальної превенції. В межах цієї інституції були об'єднані фрагментовані повноваження у сфері запобігання корупції. Вертикаль правоохоронних органів в антикорупційній сфері становлять Національне антикорупційне бюро України, на яке покладається функція досудового розслідування та здійснення оперативно-розшукової діяльності у кримінальних провадженнях з корупційних правопорушень, та Спеціалізована антикорупційна прокуратура, яка здійснює процесуальне керівництво зазначеними провадженнями. Суmтєвим недоліком цих органів є зосередження їхньоі діяльності лише на корупції вищих державних службовців, тоді як факти корупції посадовців середньоі та нижчої ланки перебувають під юрисдикцією органів Національної поліції та прокуратури. Така фрагментація повноважень призводить до міжвідомчих конфліктів, ускладнення проведення досудового розслідування та, як наслідок, зниження ефективності діяльності правоохоронної системи загалом.

Ключові слова: антикорупційні органи, антикорупційне законодавство, антикорупційна діяльність, правова політика, суб'єкти антикорупційної правової політики.
Kalugina I. O. Subjects of formation, implementation and ensuring of anti-corruption legal policy in Ukraine

The article is devoted to the study of the powers and activities of the subjects of formation, implementation and maintenance of anti-corruption legal policy in Ukraine. It is substantiated that in recent decades corruption remains one of the most dangerous problems that threatens the normal economic and political development of the state. The spread of corruption in the world is accelerating in the context of globalization, as economic crises go far beyond nation-states and become internationally important. For Ukraine, this problem is particularly acute: corruption in the country has covered almost all spheresof public life, acquiredsignsof systemicity and has become a threat to national security, which makes it especially important to implement measures to combat and combat it. To this end, in Ukraine in the period from 2014 to 2020, a number of legislative acts were adopted, which outlined the vector of development of anticorruption reform and laid the foundation for the creation of specialized anti-corruption bodies.

It is proved that the key role in the formation and implementation of anti-corruption policy in the country is played by the National Agency for Prevention of Corruption, which should be considered a body of regulation and general prevention. The vertical of law enforcement agencies in the anti-corruption sphere consists of the National Anti-Corruption Bureau of Ukraine, which is responsible for pre-trial investigation and investigative activities in criminal proceedings of corruption offenses, and the Specialized Anti-Corruption Prosecutor's Office, which provides procedural guidance. A significant shortcoming of these bodies, in our opinion, is the focus of their activities only on the corruption of senior civil servants, while the facts of corruption of middle and lower level officials are under the jurisdiction of the National Police and the Prosecutor's Office. Such fragmentation of powers leads to interdepartmental conflicts, complicates pre-trial investigations and, as a result, reduces the efficiency of the law enforcement system as a whole.

Key words: anti-corruption bodies, anti-corruption legislation, anti-corruption activities, legal policy, subjects of anti-corruption legal policy.

() Калугіна І. О., 2020 
Постановка проблеми та іï актуальність. Упродовж останніх десятиліть корупція залишається однією з найнебезпечніших проблем, яка постала перед українською державою. Сучасний досвід свідчить, що вона набуває ознак організованої злочинної діяльності, нових, високоорганізованих форм, виступаючи засобом забезпечення не тільки корисливого, а й політичного інтересу. Поширенню корупційної злочинності сприяють незадовільний стан управління державними справами і суспільства, слабкість економічної та організаційної основи функціонування публічної служби, утвердження на рівні суспільства психології вседозволеності. Цілком справедливою $\epsilon$ позиція А. Новака, який наголошує, що корупція $\epsilon$ складним соціально-політичним явищем, значно ширшим за сукупність кримінальних проявів; при цьому вона виникає і поширюється в політичній, економічній, соціальній сферах суспільства шляхом деформації нормативно визначених форм, методів та механізмів управлінської діяльності [1, с. 38]. Подальшому поширенню корупції у світі сприяє також глобалізація, яка, з одного боку, опосередковує інтенсифікацію міжнародного економічного співробітництва, а з іншого - прискорює економічні кризові явища, які мають у собі значний корупціогенний потенціал.

Більшість наслідків корупційних правопорушень призводить до фрагментації державної політики, негативно впливає на стан захищеності прав і свобод людини [1, с. 38]. Корумпованість посадових осіб органів публічної влади негативно впливає на суспільні відносини в державі, призводить до деформації діяльності державних інституцій, що, своєю чергою, має наслідком зниження рівня довіри до влади загалом.

Для України проблема корупції останніми роками набула особливої гостроти. Корупційні прояви в тому чи іншому вигляді поширюються не лише на чиновників вищої ланки, які, з огляду на особливості політичної системи держави, завжди відзначались високим рівнем корумпованості, але й на службовців нижчого рангу. Корупція проникає в усі сфери суспільного життя, призводить до зростання рівня злочинності, причому не лише економічної, а й загальної, i, набуваючи ознак системності, перетворюється на загрозу національній безпеці держави і ставить під питання іiі нормальне функціонування.

Останніми роками в Україні відбулись кардинальні зміни в політичній системі та їі основних інститутах. Одним з найважливіших складників цього процесу стала реалізація антикорупційної реформи. На їі виконання у 2014 р. було прийнято Закон України «Про запобігання корупції», який окреслив основний вектор розвитку державної антикорупційної політики, а також заклав законодавчу базу для формування іiі інституційної системи. Водночас питання комплексності та послідовності здійснюваних реформ у сфері боротьби із корупцією загалом залишається відкритим. Аналіз чинної нормативно-правової бази дає підстави зробити висновок, що законодавець акцентує увагу на окремих аспектах антикорупційної політики (декларування доходів, подальша розбудова змістової конструкції злочинів, пов'язаних із отриманням неправомірної вигоди державними службовцями, процесуальні питання і особливості розслідування таких злочинів). Разом із тим низка важливих завдань, таких як критерії ефективності напрямів і форм антикорупційної діяльності, відповідальність суб'єктів антикорупційної діяльності, взаємодія суб'єктів антикорупційної діяльності, підвищення рівня правосвідомості населення, залишаються поза його увагою, що негативно позначається як на якості державної антикорупційної політики загалом, так і на практичному іï застосуванні зокрема. Особливої гостроти зазначені протиріччя набули в інституційній системі антикорупційної політики.

Такий висновок підтверджується результатами міжнародних досліджень. Так, в Індексі сприйняття корупції міжнародної неурядової організації Transparency International у 2020 році Україна посіла 117-е місце, набравши 33 бали, опинившись на одній ланці з Єгиптом, Непалом, Свазілендом, Замбією та Сьєрра-Леоне [2]. Однак, незважаючи на деякий прогрес (для порівняння в Індексі 2019 р. Україна мала 30 балів і 124-е місце), загалом ситуація із корупцією в країні залишає бажати кращого. Цей результат наочно демонструє, що створення нормативно-правової бази і вертикалі відповідних органів зовсім не гарантує своєчасного й належного вирішення проблеми.

Аналіз останніх досліджень i публікацій. Дослідженню різних аспектів державної антикорупційної політики України останніми роками присвячені роботи таких вітчизняних учених, як Т. Брус, І. Беззуб, І. Бойко, В. Дем'янчук, Д. Заброда, В. Ковальов, О. Кущ, А. Новак, О. Новіков, М. Попов, М. Хавронюк тощо. Крім того, увагу проблемам імплементації антикорупційної політики приділяють зарубіжні дослідники, зокрема: Т. Бергер, Л. Грей, І. Россі, К. Хансен та інші. Разом із тим прагнення України стати рівноправним членом міжнародного співтовариства, 
євроінтеграційна спрямованість іï політики, а також необхідність розбудови справедливого правопорядку робить необхідним продовження проведення досліджень щодо суб'єктного складу антикорупційної політики.

Метою статті $\epsilon$ дослідження особливостей діяльності суб'єктів, уповноважених на формування, реалізацію та забезпечення антикорупційної політики України.

Виклад основного матеріалу. Незаперечним $\epsilon$ той факт, що впродовж останніх десятиліть корупція залишається однією з найнебезпечніших проблем і вийшла за межі національної держави, перетворилась на транскордонну проблему. У низці міжнародних правових актів і документів приділяється значна увага питанням формування та організації роботи спеціалізованих антикорупційних інститутів. Так, Конвенція ООН проти корупції вимагає від держав-учасниць створення двох типів інституцій: орган (органи), що запобігає корупції, та орган (органи) і особи, які спеціалізуються на боротьбі з корупцією за допомогою правоохоронних заходів [3].

Схожа позиція викладена у Кримінальній конвенції про боротьбу з корупцією 1999 р. Крім того, з положень ст. 20 зазначеної Конвенції випливають три основні вимоги до таких органів: самостійність; наявність спеціально підготовленого і кваліфікованого персоналу; забезпечення належної підготовки і фінансових ресурсів, необхідних для діяльності відповідних органів [4].

Ще в 2004 р. Організацією економічного співробітництва і розвитку в межах Стамбульського плану дій боротьби проти корупції Україні було рекомендовано, по-перше, створити спеціалізовані антикорупційні прокурорські служби, i по-друге, розглянути питання створення національного антикорупційного органу, який би спеціалізувався та мав би повноваження з виявлення, розслідування та переслідування корупційних правопорушень. Своєю чергою Група держав проти корупції (GRECO) у своєму Оціночному звіті щодо України зазначила, що має існувати чіткий розподіл між реалізацією загальних превентивних реформ та підвищенням ефективності правоохоронної системи, з метою чого необхідним видавалося створення органу, що не матиме правоохоронних функцій і здійснюватиме нагляд за реалізацією національної антикорупційної стратегії [5, с. 160-161]. Як бачимо, в ході проведення антикорупційної реформи 2014 р. законодавцем було враховано зазначені рекомендації та положення міжнародних нормативних актів, що мало наслідком створення спеціалізованих органів запобігання корупції і концентрацію в їх межах фрагментованих повноважень з боротьби з нею.

На сучасному етапі система суб'єктів антикорупційної політики в Україні має такий вигляд:

- спеціально уповноважені суб'єкти у сфері протидії корупції - органи прокуратури, Національної поліції, Національне антикорупційне бюро України, Національне агентство з питань запобігання корупції (абз. 13 ч. 1 ст. 1 Закону України «Про запобігання корупції»);

- Спеціалізована антикорупційна прокуратура (п. 5 ч. 1 ст. 7 Закону України «Про прокуратуру»); - Вищий антикорупційний суд України (п. 2 ч. 2. ст. 31 Закону України «Про судоустрій і статус суддів»);

- Національне агентство з питань виявлення, розшуку та управління активами, одержаними від корупційних та інших злочинів.

Крім того, повноваження з формування, реалізації та забезпечення антикорупційної політики в Україні мають також органи загальної компетенції, зокрема:

а) Верховна Рада України - визначає засади антикорупційної політики (Антикорупційну стратегію); проводить парламентські слухання з питань ситуації щодо корупції, затверджує та оприлюднює щорічну національну доповідь щодо реалізації засад антикорупційної політики; здійснює антикорупційну експертизу проєктів нормативноправових актів, внесених на розгляд Верховної Ради України народними депутатами;

б) Кабінет Міністрів України - утворює Національне агентство з питань запобігання корупції (далі - НАЗК); реалізує Антикорупційну стратегію шляхом затвердження та виконання державної програми, яка розробляється НАЗК; розглядає і схвалює проєкт національної доповіді щодо реалізації засад антикорупційної політики; визначає порядок проведення спеціальної перевірки; визначає порядок проведення службового розслідування щодо виявлення причин та умов вчинення корупційного або пов'язаного з корупцією правопорушення [6].

Особливої уваги, на нашу думку, заслуговує питання віднесення до суб'єктів антикорупційної політики Президента України. Так, Законом України «Про Національне антикорупційне бюро України» Президенту України було надано низку установчих повноважень, зокрема: утворення НАБУ; призначення та звільнення з посади Директора НАБУ; призначення трьох осіб до складу конкурсної комісії на зайняття посади Директора НАБУ; 
призначення члена комісії зовнішнього контролю; затвердження положення про Раду громадського контролю [7]. Проте рішенням Конституційного Суду України від 16.09.2020р. наведені положення були визнані неконституційними.

У мотивувальній частині рішення колегія суддів вказує, що повноваження Президента України визначаються виключно Конституцією України і не підлягають розширенню законом чи іншим нормативно-правовим актом. На думку Суду, наділення Президента України установчими повноваженнями щодо НАБУ $є$ перевищенням повноважень, оскільки перелік посадових осіб, яких призначає Президент України, наведений в Основному Законі і $є$ вичерпним. Виходячи з того, що НАБУ не $\epsilon$ дорадчим чи консультативним органом, а має ознаки органу виконавчої влади, Суд доходить висновку, що Президент України не може здійснювати повноваження щодо його формування [8]. Разом із тим на цю проблему $є$ інший погляд. Зокрема, суддя В. Лемак в окремій думці зазначив, що Президент України має низку самостійних повноважень у сфері виконавчої влади, які прямо зазначені в Конституції України. Більше того, у разі «конкуренції» повноважень глава держави має законодавчо закріплений безумовний пріоритет, а отже, факт віднесення НАБУ до категорії органів виконавчої влади не може розглядатись як обставина, що автоматично виводить його з-під правового регулювання Президента України [9].

Схожої точки зору дотримується суддя В. Колісник, який наголосив, що такі повноваження випливають зі статусу Президента України як глави держави, входячи до категорії «прихованих повноважень» (inherent powers) [10]. Слід відзначити, що визнання неконституційними положень про участь глави держави у формуванні кадрового складу НАБУ можуть спричинити небажані правові наслідки, зокрема, поставити питання про правомірність існування і функціонування цього органу як такого. «Дефіцит легітимності» Бюро матиме не тільки репутаційні втрати, а й справить негативний вплив на незадовільний стан боротьби з корупцією в країні.

3 огляду на обмеженість за об'ємом цього дослідження, вважаємо за необхідне більш детально зупинитись на особливостях функціонування спеціалізованих суб'єктів формування та реалізації антикорупційної політики.

Суб'єктом загальної компетенції в антикорупційній сфері $\epsilon$ Національне агентство з питань запобігання корупції, офіційна діяльність якого розпочалась 15 серпня 2016 року. Стаття 4 Закону
України «Про запобігання корупції» (далі - Закон) визначає, що Національне агентство $€$ центральним органом виконавчої влади зі спеціальним статусом, який забезпечує формування та реалізує державну антикорупційну політику [6]. Наведене визначення свідчить про те, що саме НАЗК відіграє ключову роль в імплементації антикорупційного законодавства і подальшій розбудові антикорупційної політики в державі.

На виконання цієї стратегічної мети законодавство наділяє НАЗК широким колом повноважень, які у найбільш загальному вигляді можна розподілити за такими напрямами: аналіз ситуації з корупцією і розробка Антикорупційної стратегії, державної програми з ії реалізації, координація їх виконання; виявлення корупційних норм у законодавстві та проєктах нормативно-правових актів; контроль дотримання правил етичної поведінки, законодавства щодо запобігання конфлікту інтересів у діяльності публічних службовців; координація і надання методичної допомоги органам державної влади і місцевого самоврядування у виявленні та усуненні корупціогенних ризиків у їхній діяльності, погодження і контроль за виконанням антикорупційних програм у цих органах; контроль та перевірка декларацій публічних службовців, моніторинг способу їх життя; спостереження за фінансовою діяльністю політичних партій (дотримання обмежень щодо фінансування, перевірка законності та цільового використання бюджетних коштів, розподіл державних фінансових ресурсів між партіями); робота з викривачами; адміністрування державних реєстрів [11].

Концентрація функцій публічного управління у сфері запобігання корупції в межах єдиного багатопрофільного органу повинна сприяти консолідації антикорупційної політики, завдавати різноспрямованим зусиллям з ії реалізації єдиний вектор розвитку, забезпечувати іï обґрунтованість, а також координувати міжінституційну діяльність держави в різних сферах суспільного життя. Як відзначалось вище, корупція $є$ складним соціально-політичним явищем, яке зумовлюється комплексом причин, тому цілком слушною $\epsilon$ думка В. Дем'янчука про те, що ефективна боротьба з нею можлива лише за умови проведення ефективної політики у сфері соціального та пенсійного забезпечення, правового просвітництва, оподаткування, бюджетування [12, с. 152]. Однак рішенням Конституційного Суду України від 27 жовтня 2020 р. було визнано неконституційними низку положень Закону, що призвело до суттєвого обмеження повноважень Національного агентства. 
Зокрема, зміни торкнулись таких його функцій: припинено доступ до публічної частини Реєстру декларацій; скасовано повноваження контролювати своєчасність подання декларацій, перевіряти їх повноту та достовірність, робити запити й отримувати пояснення від суб'єкта декларування; НАЗК позбавлено можливості розглядати і реагувати на звернення громадян про порушення вимог декларування; чиновники не зобов'язані повідомляти про суттєві зміни у майновому стані; позбавлено права складати протоколи про адміністративні правопорушення і вживати заходів для притягнення порушника до відповідальності; позбавлено права ініціювати притягнення порушників антикорупційного законодавства до юридичної відповідальності [11].

В обґрунтування своєї позиції Конституційний Суд зазначає, що наділення НАЗК контрольними повноваженнями має прямий i безпосередній вплив на судову гілку влади, що за стандартами конституціоналізму та цінностями Конституції України $\epsilon$ неприпустимим. Крім того, процес перевірки на предмет виявлення корупції, звільнення та притягнення до відповідальності осіб, які не пройшли перевірки, може використовуватись як інструмент для зловживання та усунення політично «небажаних» суддів. Оскільки категорії державних службовців мають різні рівні відповідальності та повноваження, на думку Конституційного Суду, необхідно забезпечити різні правила декларування [13]. Позиція Суду однозначна: за допомогою наданих повноважень Національне агентство як орган виконавчої влади здійснює неправомірний контроль за діяльністю органів судової влади, причому, на думку колегії, такий контроль може мати навіть суто протиправний, політичний характер.

Така позиція має чимало супротивників. Так, С. Головатий зазначає у розбіжній думці, що наділення НАЗК окремими контрольними функціями та повноваженнями не може розглядатись як контроль над судовою владою, оскільки відповідні повноваження не $\epsilon$ втручанням у професійну діяльність суддів. Крім того, суддя справедливо наголошує на тому, що обґрунтування використане для визнання неконституційними положень Закону загалом, а не лише в частині, що поширюється на суддів системи судоустрою і Конституційного Суду, що позбавляє зазначену позицію юридичного обґрунтування [14].

Схожу думку висловлює О. Первомайський, який визнає, що у Рішенні акцентовано увагу на проблемах здійснення органом виконавчої влади контролю та моніторингу винятково щодо суддів системи судоустрою і Конституційного Суду та проігноровано те, що конституційне подання та формально саме Рішення стосувалось всіх чиновників [15]. 3 огляду на важливість забезпечення комплексності, обґрунтованості та поступальності антикорупційної реформи вважаємо обмеження повноважень НАЗК дискусійним, оскільки такий крок призведе до нівелювання правового статусу цього органу, фактично перетворивши його на «правову фікцію», що, своєю чергою, призведе до регресу антикорупційної системи загалом.

Особливе місце серед суб'єктів реалізації антикорупційної політики посідає Національне антикорупційне бюро України. На відміну від НАЗК, яке слід вважати органом регуляції та загальної превенції, НАБУ відповідає за найбільш специфічну функцію правореалізації - правоохоронну. Саме вона покладена в основу правового статусу цієї інституції, яка Законом України «Про Національне антикорупційне бюро України» (далі - Закон про Національне Бюро) визначається як державний правоохоронний орган, на який покладається попередження, виявлення, припинення, розслідування та розкриття корупційних правопорушень, віднесених до його підслідності, а також запобігання вчиненню нових [7].

Підслідність НАБУ визначена у ст. 216 Кримінального процесуального кодексу України і опосередковується такими спеціальними умовами, як: склад злочину: у частині 5 зазначеної статті міститься вичерпний перелік злочинів, які уповноважені розслідувати детективи НАБУ; суб'єкт злочину: вищі посадові особи, уповноважені на виконання функцій держави або місцевого самоврядування (в т.ч. політичні посади); державні службовці, посади яких віднесені до категорії «A»; вищі посадові особи правоохоронних і судових органів; предмет злочину: розмір у п'ятсот і більше разів перевищує розмір прожиткового мінімуму для працездатних осіб, встановленого законом на час скоєння злочину [16].

Таким чином, незважаючи на статус спеціалізованого антикорупційного органу, Національне Бюро не $\epsilon$ органом виключної підслідності у провадженні корупційних правопорушень. Окрім нього, досудове розслідування цих злочинів здійснюють органи Національної поліції, Служби безпеки України, Державного Бюро розслідувань. Крім того, у перспективі створення Бюро фінансових розслідувань як спеціального правоохоронного органу з розслідування економічних злочинів також поставить питання про 
розмежування повноважень у цій сфері. Така фрагментація повноважень має негативний вплив на стан боротьби з корупцією, оскільки призводить до виникнення численних міжвідомчих конфліктів і ускладнює проведення досудового розслідування у кримінальному провадженні. На нашу думку, більш доцільною $є$ концентрація повноважень із розслідування корупційних злочинів у межах одного органу з обов'язковим забезпеченням його необхідними матеріальними ресурсами та працівниками належної кваліфікації.

Комплексний аналіз повноважень, наведених у ст. 16-17 Закону про Національне Бюро, дає змогу стверджувати, що НАБУ у своїй діяльності виконує три основні функції: досудове розслідування; оперативно-розшукову діяльність; інформаційно-аналітичну профілактичну діяльність. Крім того, Національне Бюро виконує низку допоміжних функцій, серед яких: гарантування безпеки, зв'язків із громадськістю, управління персоналом, матеріального забезпечення, здійснення юридичних дій та міжнародного співробітництва [5, с. 163]. Особливої уваги, на нашу думку, заслуговує дослідження функції досудового розслідування, яка $\epsilon$ ключовою в діяльності НАБУ.

Згідно з ч. 1 ст. 38 Кримінального процесуального кодексу України органом досудового розслідування у структурі НАБУ $є$ підрозділ детективів. Така структурна одиниця була утворена за рахунок об'єднання слідчих та оперативних підрозділів, внаслідок чого детективи були законодавчо наділені не лише повноваженнями зі здійснення досудового розслідування, а й оперативно-розшукових заходів у кримінальному провадженні. Як пояснюють автори законопроєкту, це рішення дасть змогу розширити обізнаність суб'єктів боротьби з корупцією, які зможуть найбільш ефективно та об'єктивно використовувати отриману інформацію для встановлення даних про кримінальне правопорушення, збирання доказів участі у ньому конкретних осіб та процесуального закріплення фактичних даних щодо обставин злочинної діяльності. Крім того, за задумом законодавця така форма організації діяльності НАБУ сприятиме мінімізації ризиків витоку інформації щодо осіб, які підозрюються в корупції, та запланованих чи здійснюваних стосовно них заходів [17, с. 156].

Однак $є$ протилежна точка зору, висловлена Головним юридичним управлінням Апарату Верховної Ради України. У рекомендаціях до законопроєкту його фахівцями було відзначено, що така законодавча новела суперечить прийнятій у державі загальній концепції досудового розслідування, для якої прийнятним $є$ розмежування функцій слідчих та оперативних підрозділів. Причому така «спеціалізація» співробітників цих підрозділів викликана істотними відмінностями у цілях, формах, методах і засобах роботи під час виконання кожної з цих функцій [17, с. 156-157].

На нашу думку, поєднання в особі детектива повноважень слідчого і співробітника оперативного підрозділу не є виправданим. Слід погодитись з точкою зору тих дослідників, які наголошують на тому, що характер цих видів процесуальної діяльності суттєво різниться як за формою, так і за змістом. Особливо це стосується проведення негласних слідчих (розшукових) дій, які за своїм характером вимагають від особи, яка їх здійснює, наявності спеціальних знань та специфічної підготовки. Поєднання цих різноспрямованих функцій у діяльності детектива призводить до невиправданого збільшення навантаження на посадову особу, зниження якості їі роботи, а отже, і якості здійснення розслідування кримінального провадження загалом.

Найкращим підтвердженням справедливості цієї тези є результати роботи НАБУ, які наглядно демонструють, що для успішної протидії корупції не досить змінити управлінську і організаційну структуру антикорупційних органів та збільшити ii фінансування. Зокрема, як свідчить витяг із видаткової частини державного бюджету, розмір загального фонду бюджетних коштів, призначених для Національного антикорупційного бюро, становить 1065797 тис. грн, з яких на оплату праці припадає 760933 тис. грн, на видатки розвитку - 65797 тис. грн [18]. Однак, незважаючи на цифру витрат та політичні декларації, можна констатувати, що натепер діяльність цього органу залишає бажати кращого. Так, станом на 31 грудня 2020 р. на стадії досудового розслідування в Національному Бюро перебувало 805 кримінальних проваджень; при цьому до суду було направлено 300 обвинувальних актів [18]. 3 урахуванням ситуації з корупцією в країні наведені цифри навряд чи можна назвати вражаючими. Крім того, не додає позитивного сприйняття новоствореному антикорупційному органу також його пасивність у складних справах, які отримали значний суспільний резонанс. Наприклад, у справі газодобувної компанії “Вurisma”, яка набула міжнародного характеру, НАБУ фактично самоусунулось від проведення розслідування і перевірки фактів міжнародної корупції, які неодноразово опинялись у центрі уваги не тільки міжнародного 
співтовариства, а й в державі. Очевидно, що така неоднозначність позиції не може викликати довіри суспільства та завдає серйозного удару по репутації Національного Бюро.

Особливе місце у системі антикорупційних органів посідає Спеціалізована антикорупційна прокуратура (далі - САП). Відповідно до ч. 5 ст. 8 Закону України «Про прокуратуру» (далі - Закон про прокуратуру) САП утворюється в Офісі Генерального прокурора на правах самостійного структурного підрозділу, на який покладаються такі функції, як: здійснення нагляду за додержанням законності під час проведення оперативно-розшукової діяльності, досудового розслідування НАБУ; підтримання державного обвинувачення у відповідних провадженнях; представництво інтересів громадянина або держави у суді у визначених законом випадках, пов'язаних із корупційними або пов'язаними із корупцією правопорушеннями, а також представництво у межах компетенції інтересів держави у справах про визнання необґрунтованими активів та їх стягнення у дохід держави [19].

Як відзначає М. Руденко, незважаючи на те, що САП утворюється як структурний підрозділ Офісу Генерального прокурора, вона $\epsilon$ автономною від нього не лише в організаційному, а й структурному відношенні, оскільки покладені на неї функції характеризуються специфічними ознаками: особливий предмет діяльності (корупційні або пов'язані з корупцією правопорушення); особливий об'єкт діяльності (НАБУ), для забезпечення функціонування якого САП по суті і створюється [20, с. 174]. На нашу думку, така позиція не $\epsilon$ виправданою. Проаналізувавши положення Закону про прокуратуру, можна зробити висновок, що правовий статус САП відзначається деякою двозначністю.

3 одного боку, очевидним є бажання законодавця надати новоствореному органу самостійності. Так, з цією метою Закон про прокуратуру був доповнений статтею $8^{1}$, якою визначаються основні гарантії, покликані забезпечити незалежність САП. До них належать: особливий порядок призначення антикорупційних прокурорів та зайняття адміністративних посад; місце розташування САП - окремо від інших службових приміщень Офісу Генерального прокурора; структура - центральний апарат і територіальні філії, які розташовані в тих самих містах, в яких знаходяться територіальні управління НАБУ; підпорядкування керівника САП виключно Генеральному прокурору; особливий порядок здійснення досу- дового розслідування та процесуального керівництва ним щодо антикорупційного прокурора [19].

Разом із тим дослідження інших положень Закону про прокуратуру дає підстави стверджувати, що в його тексті наявні суперечності і правові колізії, які нівелюють автономність їі правового статусу. Такими колізіями, наприклад, $\epsilon:$ погодження утворення, визначення питань структури та штату САП Генеральним прокурором з Директором НАБУ, що, на думку І. Ковальчук, призведе до руйнування єдності прокурорської системи [21, с. 128]; Генеральному прокурору та його заступникам забороняється давати вказівки прокурорам САП щодо реалізації ними їхніх повноважень (абз. 2 ч. 5 ст. $8^{1}$ Закону про прокуратуру). Одночасно ч. 3 ст. 17 зазначеного Закону надає право прокурору вищого рівня давати вказівки прокурору нижчого рівня, погоджувати прийняття ним певних рішень та здійснювати інші дії, що безпосередньо стосуються реалізації ним функцій прокуратури. Частина 5 статті $8^{1}$ Закону про прокуратуру встановлює ієрархію між прокурорами САП; у цій же статті міститься положення про те, що керівник САП перебуває у безпосередньому підпорядкуванні Генерального прокурора [19]. Виходячи з цієї конструкції, Генеральний прокурор має право давати вказівки з приводу реалізації функцій прокуратури керівнику САП як прокурору нижчого рівня і своєму заступнику, що прямо суперечить принципу автономності і незалежності САП.

Таким чином, можна стверджувати, що натепер двозначність у правовому статусі САП залишається, що має негативний вплив на ефективність діяльності цього органу. Очевидно, цьому сприяла відсутність системного i ґрунтовного аналізу положень Закону про прокуратуру під час прийняття до нього відповідних змін, а також намагання законодавця штучно вмістити САП як спеціалізований антикорупційний орган у централізовану систему прокуратури, не порушивши при цьому ії цілісності. На нашу думку, необхідне належне законодавче врегулювання питання співвідношення і співробітництва САП і прокуратури.

Висновки. Упродовж останніх десятиліть корупція залишається однією з найнебезпечніших проблем, яка загрожує нормальному економічному та політичному розвитку держави. Поширення корупції у світі прискорюється в умовах глобалізації, оскільки економічні кризові явища виходять далеко за межі національних держав та набувають міжнародного значення. Для України зазначена проблема відзначається 
особливою гостротою: корупційні прояви в державі охопили практично всі сфери суспільного життя, набули ознак системності і перетворились на загрозу національній безпеці, що зумовлює особливу важливість реалізації заходів протидії та боротьби з нею. 3 цією метою в Україні в період з 2014 по 2020 рр. було прийнято низку законодавчих актів, якими був окреслений вектор розвитку антикорупційної реформи та закладено основу для створення спеціалізованих антикорупційних органів.

Ключову роль у формуванні та реалізації антикорупційної політики в державі відіграє Національне агентство з питань запобігання корупції, яке слід вважати органом регуляції та загальної превенції. В межах цієї інституції були об'єднані фрагментовані повноваження у сфері запобігання корупції. Вертикаль правоохоронних органів в антикорупційній сфері становлять Національне антикорупційне бюро України, на яке покладається функція досудового розслідування та здійснення оперативно-розшукової діяльності у кримінальних провадженнях з корупційних правопорушень, та Спеціалізована антикорупційна прокуратура, яка здійснює процесуальне керівництво зазначеними провадженнями. Суттєвим недоліком цих органів $\epsilon$ зосередження їхньої діяльності лише на корупції вищих державних службовців, тоді як факти корупції посадовців середньої та нижчої ланки перебувають під юрисдикцією органів Національної поліції та прокуратури. Така фрагментація повноважень призводить до міжвідомчих конфліктів, ускладнення проведення досудового розслідування та, як наслідок, зниження ефективності діяльності правоохоронної системи загалом.

\section{Література}

1. Новак А.М. Формування та реалізація національної антикорупційної політики в умовах глобалізації: сучасні виклики. Державне управління та місцеве самоврядування. 2018. № 2. С. 35-41.

2. ИВК за 2020 год: глобальные выводы. URL: https: / / www.transparency.org/ru/news/cpi-2020global-highlights (дата звернення: 06.02.2021).

3. Конвенція Організації Об'єднаних Націй про боротьбу 3 корупцією : Конвенція від 31.10.2003 p. URL: https://zakon.rada.gov.ua/laws/ show/995_c16\#Text (дата звернення: 10.02.2021).

4. Кримінальна конвенція про боротьбу 3 корупцією : Конвенція Ради Європи № ETS 173 від 27.01.1999. URL: https://zakon.rada.gov.ua/laws/ show/994_101\#Text (дата звернення: 10.02.2021).
5. Легін А.В. Національне антикорупційне бюро України: структура, повноваження та функції. Haуковий вісник Ужгородського національного універcumemy. 2019. № 54. C. 160-163.

6. Про запобігання корупції : Закон України від 14.10.2014 р. № 1700-VII / Верховна Рада України. URL: https://zakon.rada.gov.ua/laws/ show/1700-18\#Text (дата звернення: 10.02.2021).

7. Про Національне антикорупційне бюро України : Закон України від 14.10.2014 р. № 1698-VII / Верховна Рада України. URL: https://zakon.rada.gov.ua/ laws/show/1698-18\#Text (дата звернення: 10.02.2021).

8. Рішення Конституційного Суду України № 11-р/2020 від 16.09.2020 р. / Конституційний Суд України. URL: https://zakon.rada.gov.ua/laws/ show/v011p710-20\#n62 (дата звернення: 10.02.2021).

9. Окрема думка судді Конституційного Суду України Лемака В.В. стосовно Рішення від 16.09.2020 р. № 11-p/2020 / Конституційний Суд України. URL: https://zakon.rada.gov.ua/laws/show/ na11d710-20\#Text (дата звернення: 10.02.2021).

10. Окрема думка судді Конституційного Суду України Колісника В.П. стосовно Рішення від 16.09.2020 р. № 11-p/2020 / Конституційний Суд України. URL: https://zakon.rada.gov.ua/laws/show/ nb11d710-20\#n2 (дата звернення: 10.02.2021).

11. Національне агентство з питань запобігання корупції : офіційний сайт. URL: https: / /nazk.gov.ua/ uk/pro-nazk/ (дата звернення: 12.02.2021).

12. Дем'янчук В.А. Досвід реалізації антикорупційної політики в Польщі та Німеччині: уроки та застереження для України. Вісник ЛДУВС ім. Е.О. Дідоренка. 2017. № 4. С. 151-158.

13. Рішення Конституційного Суду України № 13-р/2020 від 27.10.2020р. / Конституційний Суд України. URL: https://zakon.rada.gov.ua/laws/show/ v013p710-20\#Text (дата звернення: 12.02.2021).

14. Розбіжна думка судді Конституційного Суду України С. Головатого стосовно Рішення від 27.10.2020 p. № 13-p/2020 / Конституційний Суд України. URL: https://zakon.rada.gov.ua/laws/show/ na13d710-20\#Text (дата звернення: 12.02.2021).

15. Окрема думка судді Конституційного Суду України Первомайського 0.0. стосовно Рішення від 27.10.2020 р. № 13-p/2020 / Конституційний Суд України. URL: https://zakon.rada.gov.ua/laws/show/ nd13d710-20\#n2 (дата звернення: 12.02.2021).

16. Кримінальний процесуальний кодекс : Закон України від 13.04.2012 р. № 4651-VI / Верховна Рада України. URL: (дата звернення: 15.02.2021).

17. Удалова Л.Д. Кримінальна процесуальна діяльність Національного антикорупційного бюро 
України. Вісник Академії адвокатури України. 2015. № 2. С. 154-160.

18. Національне антикорупційне бюро України : офіційний сaйm. URL: https://nabu.gov.ua (дата звернення: 15.02.2021).

19. Про прокуратуру : Закон України від 14.10.2014p. № 1697-VII / Верховна Рада України. URL: https:// zakon.rada.gov.ua/laws/show/1697-18\#Text (дата звернення: 17.02.2021).

20. Руденко М.В. Організаційно-правові основи Спеціалізованої антикорупційної прокуратури.
Вісник Харківського національного університету ім. В.Н. Каразіна. 2016. № 21. С. 173-176.

21. Ковальчук І.С. Проблемні аспекти організації і діяльності Спеціалізованої антикорупційної прокуратури. Науковий вісник Херсонського державного університету. 2016. № 2. С. 126-129.

Калугіна І. О., аспірантка кафедри історії і теорії держави та права Запорізького національного університету 